\title{
'N PERSPEKTIEF OP 'N SUID-AFRIKAANSE BYDRAE TOT DIE TEOLOGIE
}

\section{Inleiding}

Voordat ek oorgaan tot die behandeling van die onderwerp is 'n paar inleidende opmerkinge noodsaaklik. Uit die korrespondensie van die Universiteitsowerheid in verband met hierdie voordrag moet ek die aandag op twee sake vestig.

In die eerste plek is die volgende ruimte gelaat aan die referente: „Waar die geagte sprekers dit nodig vind kan hulle binne die raamwerk van die onderwerpe 'n eie formulering daarstel". Ek het dit as noodsaaklik geag om van hierdie reg gebruik te maak. Die onderwerp het oorspronklik gelui: 'n Perspektief op 'n teologie uit Suid-Afrikaanse bodem. Om verskeie redes kon ek my met hierdie formulering nie vereenselwig nie.

In die eerste plek kan die teologie as wetenskap nooit vooraf territoriaal begrens of bepaal word nie. 'n Suid-Afrikaanse bodem het nòg iets te maak met die subjek nòg met die objek van die teologie as wetenskap. Subjek of objek word nie bepaal of begrens deur ' $n$ bepaalde land of volk nie. So ' $n$ vooringenome standpunt lê die teologie as wetenskap 'n begrensing op wat in stryd is met sy wese en doel.

In die tweede plek wil ons toegee dat sekere rigtings of strominge in die teologiese wetenskap verbind word aan hulle land van herkoms. So word op filosofiese vlak gespreek van die Amerikaanse pragmatisme, van die Engelse Deïsme, van die Franse eksistensialisme en op teologiese vlak word gespreek van die Amerikaanse God-is-dood teologie, van die Duitse ontmitologiseringsteologie ens. Van so 'n afwykende stroming in die teologiese wetenskap met 'n eie Suid-Afrikaanse wortel, inhoud en stempel, is spreker nie bewus nie.

In die lig van bogenoemde het ek my genoodsaak geag om die onderwerp te wysig tot: 'n Perspektief op 'n Suid-Afrikaanse bydrae tot die teologie.

'n Tweede saak wat ek uit die korrespondensie met die Universiteit wil noem is: „Aanstaande jaar vier die Universiteit en die Teologiese Skool natuurlik ook sy eeufees. Soos alle ander verrigtinge van die Universiteit in 1969 , sal hierdie lesing ook in die teken van die fees staan en 'n besondere karakter 
dra". By die behandeling van die onderwerp hou ons rekening met hierdie ,besondere karakter" wat dit moet dra. En dit lê vir my daarin dat die onderwerp nie slegs abstrak prinsipieel benader sal word nie, maar dat wat hierdie inrigtings betref nagegaan sal word hoedat die teologie oor 'n tydperk van 100 jaar gedien is, met 'n enkele woord oor die toekomstaak.

\section{Begripsbepaling}

Wanneer ons spreek oor 'n bydrae tot die teologie is dit nodig dat ons baie kortliks onsself rekenskap sal gee oor wat ons verstaan onder die teologie as wetenskap en wat ons verstaan onder 'n bydrae tot die uitbouing daarvan. Oor so 'n ontsaglik wye onderwerp sal noodwendig met enkele hoofgedagtes volstaan moet word.

Wat wil die woord teologie sê? Sy Griekse oorsprong van Theos en logos sê al dadelik dit is die woord aangaande God. Die woord is alreeds vroeg deur heidense skrywers gebruik in verband met die leer oor die veelgodedom van die oudheid. Daar is egter geen beswaar om dieselfde woord te gebruik met ' $n$ nuwe inhoud daaraan nie, as die leer aangaande of kennis van die enige waaragtige God. In die loop van die tyd is die wese en doel van die teologie as wetenskap nie altyd hierin gesoek nie.

Die Aufklärung van die $18 \mathrm{e}$ eeu het die teologie beperk tot kennis van die menslike gedagtes aangaande God. Schleiermacher wou aan die begin van die $19 \mathrm{e}$ eeu 'n korrektief hierop bied. Hy soek die inhoud en doel van die teologie in die innerlike ervaring en vorme waarin die Christen sy verhouding tot God belewe. Objek van die teologie is dus die religie. Dit het die teologie verbaster tot 'n godsdienswetenskap waarmee hy die $19 \mathrm{e}$ eeu oorheers het. Die teologie is daarmee herlei tot ' $n$ vorm van antropologie. $\mathrm{Na}$ ons oortuiging val die skaduwee van Schleiermacher nog op rigtings in die teologie tot diep in die twintigste eeu.

Hierteenoor handhaaf ons as skrifgelowiges dat die teologie na sy wese en doel niks anders is en beoog nie as die wetenskaplike kennis van die enige waaragtige God. Bavinck verklaar tereg: „doel der theologie kan geen ander zijn dan dat het redelijk schepsel God kenne en, kennend Hem verheerlijke".' Kuyper knm tot dieselfde konklusie: „Het doel van de theologie lag niet in het theologisch onderzoek, noch in allerlei studie 
en geleerdheid, maar uitsluitend in God te kennen"."

Dit kan alleen in sover God Hom kenbaar maak. Van Homself het God 'n volmaakte kennis, gewoonlik genoem die theologia archetypa. Hy woon in 'n ontoeganklike lig en sonder openbaring is geen kennis van Hom moontlik nie. Die kennis van Homself maak Hy egter aan die mens bekend, gewoonlik genoem die theologia ectypa. ${ }^{3}$ Deur sy openbaring in sy Woord en werke, soos bely in art. 2 van die Nederlandse Geloofsbelydenis, is dit moontlik om Hom te ken en daardie kennis sistematies, wetenskaplik na te vors en te formuleer. Die openbaring in sy werke moet gesien word by die lig van sy Woord. In sy Woord „liggen de gegevens voor onze kennis van God, opgesloten. En nu is het de taak van de theologie om uit dat geheel van die Schrift de gegevens te putten, die kunnen dienen om ons Gods gedachten voor ons geloof en leven in ordelijken samenhang te doen kennen. Het karakter van de Heilige Schrift roept ons tot den heiligen arbeid van de theologie".

Vanselfsprekend is grondige eksegese van die Woord van God 'n sine qua non vir die uitbou van die teologie as wetenskap. In die verband moet daarop gewys word dat die vryheid van die eksegese en bygevolg die uitbouing van die teologie as wetenskap gehandhaaf moet word. Niks en niemand mag oor die Woord van God heers nie. Dit lê in ons Gereformeerde belydenis, art. 7 van die Nederlandse Geloofsbelydenis.

Onmiddellik rys dan nou die vraag wat die verband is tussen die teologie as wetenskap, en in besonder dan 'n bydrae tot die uitbouing daarvan, en die kerklike konfessie. Laat ons dadelik daarop wys dat die teologie hom ook nie deur die konfessie kan en mag laat oorheers nie. Niks mag die plek van die Woord van God inneem nie. Dit wil egter nie sê dat die konfessie vir die Gereformeerde teoloog op nonaktiwiteit gestel word nie. Die teendeel is waar. Die Gereformeerde gelowige kan en mag homself nooit van sy geloofsbelydenis losmaak nie. Sy persoonlike belydenis en die van die kerk as instituut waaraan hy verbonde is, behou"ook in die ontwikkeling van die teologiese wetenskap steeds sy dienende karakter. Dit is dienskneg tot beter verstaan en deurgronding van die Woord van God en nooit heerser oor die Woord nie. So wil die Gereformeerde konfessie ook die teologie as wetenskap dien. Hierdie vryheid van die eksegese en van die teologie as wetenskap wat deur gebondenheid aan Gods Woord en aan die konfessie as 
'n dienskneg, nie kan verloop in ongebondenheid nie lê opgesluit in die ondertekeningsformulier van bedienaars van die Woord in die Gereformeerde Kerk in Suid-Afrika. Daarin word die opening gelaat dat in die beoefening van die teologie as wetenskap deur grondige skrifstudie tot ander insigte gekom kan word as waartoe die kerk in sy belydenis gekom het, maar dan is daar ook ' $n$ kerklike weg om die belydenis konform die Skrif te bring. So wil die teologie as wetenskap diensbaar wees aan die kerk.

Die kerk kom heel dikwels voor allerlei vrae te staan. Die teologie wil daarop ' $n$ antwoord probeer gee, want „door die vragen wil Hij, die zijn kerk regeert door zijn Woord en Geest, ons leiden tot rijper en rijker inzicht in wat $\mathrm{Hij}$ van ons wil in onzen dienst van Hem".

Wanneer ons dus in 'n interfakultêre lesing aan die P.U. vir C.H.O., wat in die beoefening van die wetenskap onvoorwaardelik wil buig voor die Woord van God, 'n antwoord wil gee op die vraag watter bydrae gelewer kan word tot uitbouing van die teologie as wetenskap dan moet die volgende vir ons vasstaan:

1. Dit is ' $n$ beoefening van die teologie as wetenskap wat die Woord van God as onfeilbare kenbron erken waarin $\mathbf{H y}$ Homself openbaar.

2. As beoefenaars van die wetenskap kan en wil ons ons nie losmaak van ons Gereformeerde belydenis in sover dit diensbaar is aan ' $n$ beter verstaan van die Heilige Skrif nie.

3. Doel van die teologie as wetenskap lê nie in die weten. skap self of in die mens, of in die kerk nie, maar in „de bevordering van de zuivere kennis, aanbidding en dienst van den Drie-enigen God, de bevordering van een levend christendom. God den Here kennen en liefhebben, dat is niet op één punt blijven staan, maar dat is altijd weer opnieuw willen leren in de school van den Heiligen Geest om de heerlijkheid van Gods werken en de heerlijkheid van zijn Wezen steeds rijker te mogen kennen en anderen te doen kennen. Tot die steeds rijker kennis ons te brengen, is het doel van de theologie". In hierdie sin kan ons spreek van 'n eie bydrae tot die teologie.

\section{Die teologie in 'n krisis}

Waaruit is die vraag na ' $n$ eie bydrae tot die teologie ge- 
bore? Is dit maar 'n modegril wat hier 'n rol speel? Baie hou hulle besig met die Skrif en die kennis daarvan en ons stem moet darem ook in die koor gehoor word? Is dit miskien ' $n$ vraag wat hoop op 'n prestige-antwoord? Ons het 'n fakulteit van teologie aan ons Universiteit en dit moet darem nou ook haas iets lewer op teologiese erf!

Nee, ons beluister in hierdie vraag na 'n eie bydrae tot die teologie ' $n$ noodkreet. Op teologiese erf heers ' $n$ ongekende verwarring. Boodskappers van lig dryf die soekers na lig altyd dieper en dieper die nag in. Verdieping in die teologie as 'n Skrifgebonde wetenskap het in 'n verwarde wêreld 'n heilige roeping geword. Bestormers maak aanslae op waarhede wat vir ons as Gereformeerdes bo alle twyfel vas staan. Brutaal gryp die hand na God om Hom van sy troon te ruk. As daar ooit 'n tyd was dat die Gereformeerde teoloog diep in die Woord moet delf en kragtig moet getuig dan is dit nou.

Ons kan hier onmoontlik 'n geheelbeeld gee van wat aan die gang is op teologiese erf. Ons volstaan met enkele flitse om $\mathrm{u}$ iets te laat verstaan van die uitdaging waarvoor ons tyd staan.

Ons lewe in 'n eeu waarin die mens en sy prestasies asemrowende hoogtes bereik het. Tegnologies is alle verwagtinge oortref. Ruimtereise is al iets alledaags. Straks gaan miskien ' $n$ man op die maan land. Dit alles het nie slegs die belang. stellingsveld van die gewone man in ander bane gestuur nie, maar het ook 'n hoë bewondering opgewek vir die mens en sy vermoëns. Dit was net die regte stimulus om 'n reeds opgeblase mens op te pomp tot 'n dwase verwaandheid. Dink hierby an die invloed van ' $n$ Friedrich Nietzsche wat hierdie eeu ingelui het met sy Ubermensch. Die mens moet 'n heer en meester wees en alles wat hom in die weg staan om dit te verwesenlik moet vernietig word. Hy moet ook God en die Christendom uitwis. Tot watter brutale hoogtes wou Nietzsche die mens laat opklim! En die mens van hierdie eeu hét geklim.

Die kernvraag van die teologie van ons dag is nou of hierdie moderne mens, met ' $n$ beklemtoning van sy eie wysheid soms die mondige mens genoem, nog deur die evangelie bereik word. In plaas van dat die moderne, sogenaamde mondige mens moet buig voor die Woord van God moet die Woord van God omgebuig word om dit aanneemlik te maak vir die verligte heer van ons eeu. 
Veral word tweeërlei gedoen om hierdie sogenaamde slim mondige mens te bereik. Daar word eerstens wel aanknoping gesoek by die Bybelse evangelieboodskap en terme, maar dit word op 'n heeltemal nuwe wyse geinterpreteer.

Hiervan het ons sprekende voorbeelde in die ontmitologiseringsteologie van Bultmann, die verwerping van God as 'n ewige, onsienlike geestelike wese deur Bonhoeffer asook deur Robinson. Laasgenoemdes wil wegbreek van die ou geloof in God wat spottend genoem word "the old man in the sky". Hulle wil God neerhaal na die aarde as die onpersoonlike Grond en Diepte van die menslike bestaan. Voeg hierby die „God-is-dood” teologie van veral Altizer en Hamilton, en dit is duidelik dat die fondamente van 'n teologie wat nog onvoorwaardelik wil buig voor die Woord van God as openbaring van God, ondergrawe word.

Waar lê die ontsporing? Bevrug deur die eksistensiefilo. sofie gaan hierdie moderne strominge uit van die mens se bestaan en sy behoeftes. Van daaruit word beweeg na die Heilige Skrif, waaroor op tipies rasionalisties humanistiese wyse ydel gefilosofeer en gespekuleer word. Met so 'n ydele spekulasie uit die mens tot die mens en nie uit die Skrif tot God nie, kan jy tot enige konklusie kom.

' $n$ Tweede poging om die moderne mens te bereik is om die waarheid van die Christendom te relativeer, waarvan Karl Jaspers ' $n$ tipiese voorbeeld is. As eksistensiefilosoof het hy hom veral besig gehou met die mens en sy behoeftes. Tog het hy die mens verbonde gesien aan en afhanklik van ' $n$ god. Dit is egter nie die God van die Skrif nie maar in sy filosofiese taal 'n Transendentale werklikheid. Al die godsdienste, Christendom, Boeddhisme, Mohammedanisme, Confucianisme ens. is maar net fasette of waarhede van die een groot begrip god en godsdiens. Met so 'n sintese van gode en godsdienste is dit duidelik dat daar van die Woord as openbaring en van die God van daardie Woord as die enige ware God niks oorgebly het nie.

Maar ook binne die kring van Gereformeerde teoloë is daar onrusbarende verskynsels. Wanneer die onfeilbaarheid en gesag van die Skrif kwestieus gestel word, wanneer daar 'n vraagteken geplaas word agter die historiese bestaan van Adam en Eva, en wanneer Paulus as onbetroubaar voorgestel word vanweë Rabbynse invloede,' en wanneer binne Gereformeerde kringe in Nederland 'n onderwerp behandel word soos: „De 
invloed van de nieuwe theologie binnen de Gereformeerde kerken", dan is dit duidelik dat die krisis in die teologie nie alleenlik oplaai in moderne kringe nie maar dat daar ook al opslae is binne die Gereformeerde familie.

Sommige spreek van 'n hermeneutiese krisis, andere van 'n openbaringskrisis; die vraag is, is dit nie 'n geloofskrisis nie. Elke wetenskap gaan van bepaalde gegewens uit wat nie bewys kan word nie. Ons noem dit axioma's of grondstellinge. Die teologie begin by die geloof. Dit is die godgegewe orgaan wat die sondaarmens in staat stel „om naar God te luisteren en de dingen te zien, zoals zij zijn naar Gods bestel. Door zijn Heiligen Geest wil God onze ogen openen en ons hart ontvankelijk maken voor zijn licht. Hij komt met zijn Woord tot ons, en wij erkennen dat Woord als het Woord der waarheid waardoor wij mogen leren wie God is als onze God en Vader,... Ons innerlijk leven word vernieuwd, ons denken geheiligd. De rechte kennis van God is dan weer in beginsel mogenlijk en de kennis van de wereld en van ons eigen leven in hun verhouding tot God. Er komt dan door Gods ontferming de innerlijke verwantschap, de waarachtige liefde, die nodig is voor waarachtige kennis... De zekerheid van het geloof rust in de Heilige Schrift als Gods Woord. De erkenning hiervan is ook weer een zaak van geloof. Ik kan niet door verstandelijke redenering bewijzen, dat de Bijbel Gods Woord is, maar ik aanvaard het door de majesteit, waarmee dat Woord op mij toekomt. God spreekt en wij geloven"."

As ons 'n skrifgebonde Suid-Afrikaanse bydrae wil lewer tot die teologie as wetenskap sal ons voortdurend moet bid: gee ons 'n kinderlike maar 'n vaste geloof.

\section{Wat sê die eeu wat verby is?}

In die lig van die aankondiging dat die interfakultêre lesings van 1969 deel uitmaak van die feestelikhede van die eeufeesjaar, wil ons nou luister na die stem van die geskiedenis. Het daar in die afgelope 100 jaar iets realiseer van 'n eie bydrae tot die teologie as wetenskap?

Van die dag af dat die Teologiese Skool op 29 Nov. 1869 te Burgersdorp geopen is, is gepoog om die opleiding van bedienaars van die Woord op 'n deeglik teologies wetenskaplike peil te laat geskied. Van Skrifstudie is groot erns gemaak; hier- 
van getuig die hoë vereistes vir die studie van die ou tale. Natuurlik moet ons toegee dat vanweë gebrek aan wetenskaplik onderlegde manne en aan 'n goedtoegeruste biblioteek, in die vorige eeu seker so goed as geen bydrae gelewer is tot uitbouing van die teologie nie. Ons kan aanneem dat die eerste dertig jaar van die Skool se bestaan hoofsaaklik beheers is deur die Gereformeerde teologie van die $17 \mathrm{e}$ eeu met sy sterk bevindelike karakter, waarvan die Redelijke Godsdienst van à Brakel 'n goeie voorbeeld is asook die „Kern der Christelijke Leere” van Regidius Francken. Laasgenoemde is deur prof. D. Postma gebruik vir die opstel van 'n eie Handleiding oor die Dogmatiek. Die ideaal van 'n beter teologies wetenskaplike onderlegdheid is egter nooit uit die oog verloor nie. Wanneer die eerste voltydse professor in die teologie in 1876 benoem word, in die persoon van ds. D. Postma, bedank hy daarvoor omdat hy homself onbekwaam ag. Hy meen iemand moet gevind word "die met meer bekwaamheden is toegerust"."

In die volgende jaar 1877 ontvang die inrigting vir die Literariese Departement sy eerste voltydse professor, P. Postma, toegerus met 'n B.A.-graad. En wanneer hy deur drie studente 'n welkomsadres aangebied word, waag hy om in sy antwoord daarop te spreek van sy koms na die inrigting ,ter bevordering van de noodige kennis en wetenschappen"." Onder primitiewe toestande het van hierdie "bevordering van de wetenschappen" seker nie veel tereg gekom nie. In 1886 by die ingebruikneming van die gebou van die Vrye Christelike Skool wat nou ook die Teologiese Skool sou huisves, stel ds. M. P. A. Coetsee (jr.) weer eens as doel die bevordering van die wetenskap. En let wel, die bouers van daardie tyd wys met trots na die goedtoegeruste biblioteek van tussen 400 en 500 boeke. Hulle hou egter nie op om drome te droom nie. In sy twintigjarige feesrede 1889 meld Cachet van die strewe om God ook te dien „door de wetenschap" en waag hy selfs om te spreek van die strewe na „een hoogeren graad van kennis en wetenschappelijke ontwikkeling"."

In sy redevoering op 12 Julie 1890 by geleentheid van die indienstreding van prof. S. Postma beklemtoon ds. M. P. A. Coetsee (jr.) weer eens die noodsaaklikheid van ,de beoefening der wetenschap". ${ }^{4}$ Hy en sy tydgenote is ook geen vreemdelinge in die teologiese strominge van hulle tyd nie. Hy onderken die agnostisisme van Spencer en Darwin as 'n monster wat „de bron 
van het zeker weten met totale vernietiging bedreigt" is en wat gemik is op ' $n$ miskenning van die Godsopenbaring. Vir die bestryding van "die bewegingen en beroeringen der wetenschap" gee hy dan, in die raamwerk van sy tyd gesien, hierdie merkwaardige resep: „Het beste wapen nu om de verkeerde en verderfelijke richtingen, de valsche wetenschap en de ijdele philosophie te bestrijden is de wetenschap zelve"."

In diezelfde trant spreek daardie geniale prof. S. Postma sy inougurele rede uit op 12 Julie 1890 . Dit is vandag nog lesenswaardig vir ' $n$ insig in die onderlinge verwantskap van die wetenskappe. Ten opsigte van die Teologie pleit hy vir 'n grondige onderrig in ,de hulpwetenschappen die dienstbaar zijn aan de uitlegging der Schrift, opdat hunne uitlegging van de Schrift voldoen moge aan den eisch der belijdende gemeente niet alleen maar ook aan de redelijke eischen van een wetenschappelijk historische kritiek". Uit hierdie enkele flitse is een saak wel duidelik en dit is dat die bouers van die vorige eeu die ideaal van ' $n$ eie bydrae tot die teologie as wetenskap steeds voor oë gehou het.

En aan die begin van hierdie eeu, by die drumpel van ' $n$ ryker ontplooiing van die sekulêre wetenskappe, verskyn in 1903 aan die teologies wetenskaplike horison J. D. du Toit met sy proefskrif oor „Het Methodisme”. Van 1911 af dat hy aan die Teologiese Skool verbonde was, moes hy net soos sy voorgangers die volle teologiese wetenskap doseer. Uit die aard van die saak en vanweë ander veelvuldige pligte kon hy nooit dieper delf in ' $n$ bepaalde vak nie en so ' $n$ bydrae tot die teologie lewer met 'n eie stempel. As bewonderaar van Kuyper het dié groot geleerde 'n besondere invloed op sy denke uitgeoefen.

Die ideaal van ' $n$ altyd beter beheersing van die teologiese wetenskap is nooit uit die oog verloor nie. Dit lei tot die benoeming van meer professore aan die Teologiese Skool, wat dan ook die Fakulteit Teologie aan die P.U. vir C.H.O. ten goede gekom het.

Ten opsigte van die bevordering van die teologiese wetenskap het die benoeming van prof. $S$. du Toit ' $n$ nuwe fase ingelui. Vir die eerste keer is by die benoeming van 'n professor in die teologie op ' $n$ bepaalde vakwetenskaplike toerusting en kennis gelet. Dit is ook by latere benoeminge aan die Teologiese Skool in ag geneem. 
Dit is duidelik dat die ideaal om die teologie as wetenskap te dien deur die benoeming van vakmanne altyd sterker en sterker gespreek het. En waar die teologiese wetenskap 100 jaar gelede deur een deeltydse dosent gedien moes word, is daar vandag ses voltydse professore, almal vakmanne wat hulle kragte gegee het en nog steeds gee aan die uitbouing van die teologie as wetenskap.

Intensiewer beoefening van die teologiese wetenskap aan hierdie inrigtings het dan ook al 'n eie Suid-Afrikaanse bydrae tot die teologie gelewer. Tot op datum het ongeveer 40 studente in die fakulteit Teologie magistergrade ontvang, terwyl reeds oor die 20 doktorsgrade verwerf het.

\section{Ons toekomstaak}

Gesien teen die agtergrond van verwikkelinge in die wêreld op teologiese gebied wag daar vir die Skrifgebonde teoloog 'n magtige taak. Ons in Suid-Afrika en in besonder dan hulle aan hierdie inrigtings verbonde mag hulle deelname aan die bewaring en verdediging van ou waarhede en die ontginning van die goudmyn van Gods Woord, nie weier nie. Ons spore sal waar nodig dieper getrap en nuwe bane sal oopgetrap moet word. Ontwikkeling in die teologie weg van Skrif en konfessie beklemtoon dat die Gereformeerde teoloog Skrifgebonde antwoorde op die vrae van die dag sal moet vind. Vanselfsprekend is grondige eksegese hier van die allergrootste belang.

In die beoefening van die teologie as wetenskap kan ons ons ook nie langer meer laat lei deur die denke uit die buiteland nie. Die dae toe met volle vertroue op 'n Kuyper en Bavinck geleun is, is verby. Ons sal selfstandig in die dieptes van Gods Woord moet grawe.

Aan ons deur klop dan ook vraagstukke wat eie is aan SuidAfrika. Ons dink aan die verhouding van volkere uit verskillende rasse binne dieselfde landsgrense, met al die fasette aan die vraagstuk verbonde en die implikasies daarvan vir die sending.

Daar sal gesonde vooruitgang moet wees. Ou waarhede wat vir ons dierbaar is sal behou en verdedig moet word. Kinderlik gelowig sal ons die onfeilbaar geïnspireerde gesag van die Woord moet handhaaf. Kinderlik gelowig sal ons dit moet verdedig as die geopenbaarde waarheid waaruit ons God ken en 
kinderlik gelowig sal ons die teologie weer teologie moet maak en dit moet verlos uit die knellende en vervalsende bande van 'n mensverankerde filosofie. Wat 'n taak wag op ons! Maar deur grondige Skrifstudie sal ook nuwe waarhede ontdek moet word. Hepp spreek van 'n progressiewe Gereformeerde teologie en kwalifiseer dit dan nader soos volg: „Wat de vroegere theologie haar overleverde toetst zij telkens opnieuw aan Gods Woord. Als zij soms het snoeimes hanteert draagt zij de uiterste zorg nooit essentieele, gezonde, schriftmatige deelen weg te snijden. Zij ontdoet zich van verouderde vormen en uitdrukkingen welke thans niet meer worden verstaan. Zij spreekt de taal van onzen tijd en gebruikt de hulpmiddelen van onzen tijd. Maar ze hoedt zich angstvallig de eeuwige waarheden welke door de vroegere geslachten zuiver werden beleden te schenden. Doch behalve dat, kenmerkt zij zich ook door een honger en dorst naar meer waarheid. $\mathrm{Zij}$ raakt niet verzadigd. $\mathrm{Zij}$ gaat gedurig op nieuwe vondsten uit". ."

Aangesien hierdie 'n interfakultêre voordrag is kan ek nie nalaat om die teologie en sy toekomstaak te sien in die verband met die ander vakwetenskappe nie. Waar daar so 'n behoud van ewige waarhede uit die verlede maar terselfdertyd vanweë nuwe vraagstukke 'n voortdurende teologiese verdieping in die hede is, kan die teologie as wetenskap sy bevrugtende inwerking op die eksakte en geesteswetenskappe behou, nie as die regina scientiarum nie, want daar is net een Koning oor die wetenskappe en dit is Jesus Christus en daar is net een koningswoord en dit is die Woord van God. Alle ander wetenskappe moet van hierdie ligbron uitgaan en nie van die teologie as wetenskap nie. Maar om waarlik 'n eie bydrae aan die wêreld te lewer sal daar ook meer na mekaar geluister moet word, en wat die teologie aanbetref meer kennis geneem moet word van die resultate van die Christelike vakwetenskaplike. Is dit nie miskien 'n verwaarloosde terrein nie? Het ons in die beoefening van die teologie nie, veelal in reaksie gekom teen die theologia naturalis van die Roomse en die natuurlike godgeleerdheid van die Deissme en Rasionalisme nie, sodat ons die kennis van God deur „skepping, onderhouding en regering van die hele wêreld" "verwaarloos het nie. Bavinck sê hiervan: „Zoo is ook de theologie ten strengste gebonden aan de feiten en getuigenissen welke God in natuur en Schrift haar kennen doet". . Die teologie moet kennis neem van die resultate van 
die Christelike vakwetenskaplike. Net soos die vakwetenskappe leer van die teologie, so moet ook die teologie kennis neem en leer van die Biologie, die Plantkunde, die Dierkunde ens. tot verdieping van sy kennis van God, die Skepper, Regeerder en Onderhouer van alle dinge. Laat ons 'n baie praktiese voorbeeld noem. Die plantkundige maak 'n intensiewe studie van die ingewikkelde bevrugtings- en voortplantingsproses by plante. Dit spreek tog van die diepe en wondervolle gedagtes van die alwyse Skepper van alle dinge wat daaragter sit. Moet die teoloog nie meer erns maak van die openbaring van God in die natuur nie? In hierdie opsig het die Fakulteit Teologie aan die P.U. vir C.H.O. 'n unieke geleentheid. Dit bou aan die wetenskap in samewerking met manne en vroue wat ook in die objek van hulle studie die openbaring van God erken en dit wil ondersoek in die lig van Gods Woord. So kan deur die hande inmekaar te slaan aan die P.U. vir C.H.O. 'n korps manne en vroue die wetenskap beoefen wat teenoor 'n verwarde en ligsoekende wêreld kan proklameer: So ken ons God uit Skriftuur en natuur en aan Hom is ons diens gewy tot roem en prys van sy grote Naam.

Dat dit Gereformeerde belyders erns is met 'n eie bydrae tot die teologie blyk uit die besondere aandag wat by die uitgang van die eerste eeu en die ingang tot die tweede gegee word aan die uitbouing van die teologiese biblioteek. Soos bekend is as dankoffer met die oog op die eeufees ' $n$ eeufeesfonds in die lewe geroep, "Die gedenkfonds vir Christelike onderwys". Die deel hiervan wat die Gereformeerde Kerk in Suid-Afrika toekom sal aangewend word vir die uitbouing van 'n teologiese biblioteek, sover moontlik volgens internasionale standaarde sowel wat die huisvesting as die inhoud betref. Dit, saam met die aandag wat gegee word aan die Argief, dui daarop dat die Fakulteit Teologie van die P.U. vir C.H.O. in die eeue wat kom nog ' $n$ verdere eie Suid-Afrikaanse bydrae gaan lewer tot die uitbouing van 'n teologie wat hom wil laat lei deur die spreuke van beide inrigtings, „In U lig” en „U lig en U waarheid”.

Laat ons om 'n kinderlike geloof bid en werk, en God sal sy seën gebied.

G. C. P. van der Vyver.

Bloemfontein. 


\section{Verwysinge}

1 H. Bavinck: Gereformeerde Dogmatiek I, p. 212.

2 A. Kuyper: Encyclopaedie der Heilige Godgeleerdheid II, p. 193.

3 Vgl. Bavink: a.w., p. 212. Kuyper: a.w., p. 189 e.v.

4 B. W. Ganzevoort: Inlelding in de theologie, p. 29.

5 Idem, p. 58.

6 Idem, p. 51

7 H. M. Kuitert: Verstaat gij wat glj leest?, p. 28 e.v.

8 Idem, p. 29

$9 \mathrm{Vgl}$. Waarheid en Eenheid. Orgaan voor het gereformeerde leven. 21 jaargang. No. 9, 7 Febr. 1969.

10 Ganzevoort: a.w., p. 33, 34.

11 Acta Sin. Geref. Kerk, 1876, bylaag 6.

12 De Maandbode, 1 Maart 1877.

13 D. Postma: Geschiedenis der Gereformeerde Kerk, p. 296.

14 Idem, p. 304.

16 Idem, p. 305, 306.

17 V. Hepp: Koers in die Krisis I, p. 161, 162.

18 Art. 2 Ned. Geloofsbelydenis.

19 Bavinck: a.w., II, p. 240. 